\title{
Letter from Paul Lengrand to UNESCO, 1952 Lettre de Paul Lengrand à l'UNESCO, 1952
}

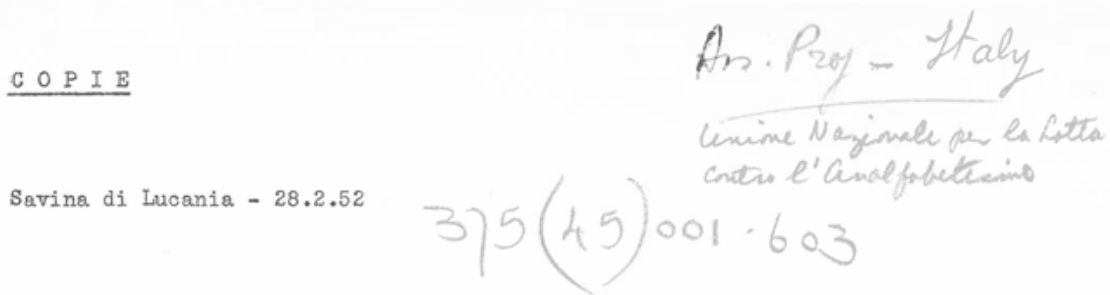

Cher Monsiever Bowers,

Je suis depuis une semaine installé dans ce trou de montagne, juché sur un piton à $800 \mathrm{~m}$. de hauteur. Je loge dans la seule maison potable de l'endroit, celle du directeur du Centre. Les autres "maisons" tiennent plutôt le caractère d'écuries que d'habitations humaines. Les cochons, les chèvres, les moutons les gens, vivent ensemble avec le seul avantage notable de se tenir chaud pendant l'hiver. On m'a dit que pendant l'été il est impossible d'y pénétrer à cause de l'odeur et des petites bêtes indésirables. Sur une population de 2000 jom habitants, 300 sont inscrits au Centre oulture populaire. Le directeur est un jeune instituteur, très intelligent et remarquable animateur comme d'ailleurs la plupart des directeurs que j'ai rencontrés jusqu'à présent. Il a réussi à obtenir le concours de tous les éléments instruits du pays, le médecin, l'avocat (il y a des avocats dans les endroits les plus perdus de l'Italie), le curé, un paysan qui a été prisonnier en Angleterre et dans l'Inde et qui a appris à cette occasion les éléments de l'agronomie moderne, sans compter les 5 instituteurs du village. Tous ces gens collaborent gratuitement au Centre, $y$ passent 3 heures le soir - de $7 \mathrm{~h}$. à $10 \mathrm{~h}$., pour guider les "Centrists" dans leur travail et leurs lectures. L'essentiel reste naturellement la lutte contre l'analphabétisme qui atteint $70 \%$ de la population. Mais cette activité technique est placée dans une ensemble culturel plus vaste qui vise à combattre la routine et l'ignorance sens toutes s̀es formes et à créer des modes de vie et d'activités collectives.

Je suis en train de travailler à un programme de cours destinés à la section culturelle (ceux qui savent lire et écríre) de ces Centres. Après 3 semaines de travail avec ces habitants de la campagne, je commence à avoir une meilleure idée de leurs besoins, de leurs besoins, de leurs dxetexerétifficultés et de leurs ressources mentales. Naturellement, ils ont un mode de pensée aussi peu rationnel que possible, se fiant pour leurs croyances et leur comportement à la tradition, à l'usage et à l'autorité. Ils ont une méfiance instinctive à l'égard des innovations. Inversement ils ont une tournure d'ésprit naturellement philosophique qui les conduit à réflechir et discuter sur les principes, liberté, justice, amour....., mais d'une manière toute abstraite qui se réfère aussi peu que possible aux faits. Ce sont presque deux mondes séparés. Il s'agit dono d'établir un pont entre ces deux domaines, de rendre le réel rationnel et le rationnel réel. C'est ainsi que l'autre soir j'ai entendu une longue discussion assez pertinente sur les relations entres les sexes, la nécessité d'arriver à une meilleure comprhension entre l'homme et la femme, etc. mais sans que personne ait songé à faire allusion à la situation existant au Centre. La séparation des sexes y est absolue; il n'existe aucune activité en commun, au point que les fenmes sont exclues de la section culturelle, faute d'instructeurs féminins.... Je orois qu'à partir de leur expérience et des moyens culturels mis à leur disposition, par l'Unione, il est possible de leur donner une idée et une certaine pratique de la pensée scientifique, comprenant l'établissement des faits, la notion d'expérience et de preuve, la recherche des causes et des lois, les liens entre la pensée et l'action. En tout cas, mes conversations avec les dirigeants de l'Unione sur le plan local aussi bien que sur le plan national me permettent 
de penser que la constitution d'une méthode de pensée conforme aux exigences de la logique pratique constitue un des buts essentiels de l'action qu'ils ont entreprise en faveur de ces populations.

Je quitterai Savina Dimanche prochain et passerai à Rome les derniers jours de ma mission pour discuter avec des gens de l'Unione les résultats de non travail dans le sud.

Je vous prie de présenter mes amitiés à mes collğues du service et de recevoir personellement l'expression de mes sentiments très dévoués.

\author{
(signé) P. Lengrand.
}


Savina di Lucania, 28.02.1952

Dear Mr. Bowers,

I have been in this godforsaken place of a mountain for a week now, perched on a peak 800 meters above sea-level.

I am staying in the only half-decent house around, that of the Director of the Center. The other 'houses' are more like stables than human dwellings. Pigs, goats, sheep, humans all live together, the only possible advantage being that of keeping warm in winter. They tell me that in summer it is impossible to enter theses house because of the stench and undesirable pests. Of a population of 2,000, 300 are enrolled in the People's Cultural Center. The Director is a young teacher, very intelligent and a remarkable activity leader, as are most of the directors I have met so far. He has managed to summon the help of all educated elements of the country, the doctor, the lawyer (there are lawyers in far flung corners of Italy), the curate, a peasant who was a prisoner of war in England and India, during which time he managed to learn some modern farming methods, plus the 5 village teachers. All these people give their time for free to the Center, spending 3 hours every evening from $7 \mathrm{pm}$ to $10 \mathrm{pm}$ to help the center-goers with their work and reading. Naturally, the greatest task is the fight against illiteracy that touches $70 \%$ of the population. But this technical activity is part of a wider cultural ensemble aiming to combat routine and ignorance in all its forms and to create collective ways of life and activities.

I am working on a lesson program for the cultural section (for those who already know how to read and write) of these Centers. After 3 weeks work with these country folk, I am starting to have a better idea of their needs, their difficulties, and their mental aptitude. Naturally, they have the least rational way of thinking possible, for their beliefs and behaviors are based on tradition, on practice, and on authority. They are instinctively wary of innovations. Inversely, they have a natural philosophical way of thinking which leads them to reflect on and discuss principles such as freedom, justice, love ..., but in an abstract way, completely unrelated to facts. They inhabit almost two separate worlds. It is necessary to build a bridge between these two domains, to make the real rational and the rational real. For example the other evening I overheard a long, quite interesting discussion on relations between the two sexes and the necessity to arrive at a better understanding between men and women, but without anyone bringing up the existing situation at the Center. There is total segregation of the two sexes, there are no common activities, to the point of women being excluded from the cultural section, due to a lack of female trainers ... I think that from their experience and the cultural means put at their disposal by l'Unione, it is possible to give them an idea and a certain practice of scientific thought, including the establishment of facts, the notion of experience and of proof, the search for causes and laws, and the links between thought and action. In any case, my conversations with the leaders of the Unione, on a local as 
well as on a national scale, allow me to think that the drawing up of a method to think, conforming to the requirements of practical logic, constitutes one of the essential goals of the action that's carried out in favor of these populations.

I am leaving Savina next Sunday and I will go to Rome at the end of my mission to discuss the results of my work in the South with the people of the Unione.

Yours sincerely,

P. Lengrand 